\title{
Intermittent hypobaric hypoxia and neuroendocrine reaction of the parvocellular neurons of the paraventricular hypothalamic nucleus
}

\author{
V. O. Shamenko ${ }^{B, C, D}$, Ye. V. Kadzharian ${ }^{B, C, D}$, A. V. Abramov*A,C,E,F
}

Zaporizhzhia State Medical University, Ukraine

A - research concept and design; B - collection and/or assembly of data; C - data analysis and interpretation; D - writing the article;

$\mathrm{E}$ - critical revision of the article; $\mathrm{F}$ - final approval of the article

Key words: hypothalamus, neuropeptides, intermittent hypobaric hypoxia, adaptation.

Pathologia 2019; 16 (3), 334-338

DOI:

10.14739/2310-1237

2019.3.188834

*E-mail: abramov@zsmu.pp.ua

The neuroendocrine system occupies an important place in the systemic mechanisms of the body response to stress. The paraventricular nuclei of the hypothalamus $(\mathrm{PVH})$ are one of the most important links of the brain's neuroendocrine system which determine the reactivity of the hypothalamic-pituitary-adrenal axis (HPA) in response to the various stressors and thereby ensure the development of adaptive reactions by the formation of body resistance to the stress.

The aim of the research was to study the functional state of the peptidergic neurons of the medial parvocellular nuclei of the paraventricular hypothalamic nucleus (PVHmp) during the multi-day action of intermittent hypobaric hypoxia and in the posthypoxic period.

Materials and methods. The research was conducted on 24 male Wistar rats. Intermittent hypoxia was modeled by a daily 6 -hour stay of rats at an altitude of $6000 \mathrm{~m}\left(\mathrm{pO}_{2}=9.8 \%\right)$ for 15 days, the posthypoxic period lasted for 10 days. The distribution of corticotropin-releasing hormone (CRH), [Arg $\left.{ }^{8}\right]$-vasopressin (AVP), $\beta$-endorphin, cFos and HIF-1 $\alpha$ proteins was studied by quantitative immunofluorescence methods in serial frontal sections of the hypothalamus.

Results. The intermittent hypobaric hypoxia stimulated the developing of mild hypertrophy of PVHmp neurons and increased the concentration of RNA in the cytoplasm by $37 \%$. An indicator of PVHmp neurons response to hypoxia was 2.5 -fold increase in the concentration of the HIF-1 $\alpha$ protein in them. IHH elevated the concentration of cFos protein in PVHmp by $37 \%$, increased the area of immunoreactivity to AVP by 2.5 times, to CRH and $\beta$-endorphin by 3 times. There was an increase in the synthesis of neuropeptides in response to hypoxia, which led to the elevation in the concentration of AVP in PVHmp by 6.6 times, $\beta$-endorphin by 7 times, and $\mathrm{CRH}$ by 8.5 times. The immunoreactivity indicators for the HIF-1 $\alpha$ protein and its concentration in PVHmp remained at a high level in the posthypoxic period. At the same time, high immunoreactivity to $\mathrm{CRH}$ and $\beta$-endorphin in PVHmp was noted, as well as a high concentration of these neuropeptides in neurons against the background of AVP synthesis inhibition in neurons. It is possible that high rates of neurosecretory activity of PVHmp in the posthypoxic period may indicate the formation of neuroendocrine mechanisms of adaptation of the HPA axis to the long-term effect of hypoxia.

Conclusions. Intermittent hypobaric hypoxia stimulates the neurosecretory activity of the PVHmp neurons, increases the synthesis and secretion of CRH and AVP hormones that activate the HPA axis. Synthesis of the secretory response indicator cFos protein and a central regulator of hypoxic responses HIF-1a protein is also increasing in the peptidergic neurons of the PVHmp. High levels of the PVHmp neurosecretory activity at the posthypoxic period are preserved and indicate the formation of neuroendocrine mechanisms of the HPA axis adaptation to the long term intermittent hypoxia exposures.

Киючові слова: гіпоталамус, нейрогормони, переривчаста гіпобарична гіпоксія, адаптація.

Патологія. - 2019. -

T. 16, № 3(47). -

C. 334-338

\section{Нейроендокринна реакція дрібнокиітинних нейронів паравентрикулярного ядра гіпоталамуса при переривчастій дії гіпобаричної гіпоксії}

\section{В. О. Шаменко, Є. В. Каджарян, А. В. Абрамов}

Нейроендокринна система посідає важливе місце в системних механізмах відповіді організму на стрес. Паравентрикулярні ядра гіпоталамуса (PVH) визначають реактивність гіпоталамо-гіпофрізарно-адренокортикальної осі у відповідь на дію стресора будь-якої природи та забезпечують розвиток адаптаційних реакцій і формування резистентності організму до стресу.

Мета роботи - вивчити особливості функціонального стану пептидергічних нейронів медіального дрібноклітинного суб'ядра паравентрикулярного ядра гіпоталамуса (PVHmp) при багатоденній дії переривчастої гіпобаричної гіпоксії та в постгіпоксичний період.

Матеріали та методи. Дослідження здійснили на 24 самцях щурів лінії Wistar. Переривчасту гіпоксію моделювали щоденним 6-годинним перебуванням щурів на висоті 6000 м ( $\mathrm{pO}_{2}=9,8$ \%) протягом 15 днів, постгіпоксичний період тривав 10 днів. Розподіл кортикотропін-рилізинг гормона (CRH), [Arg8]-вазопресина (AVP), ß-ендорфіну, білків cFos та HIF-1 $\alpha$ досліджували методами кількісної імунофлуоресценції в серійних фронтальних зрізах гіпоталамуса.

Результати. Переривчаста гіпобарична гіпоксія стимулювала помірну гіпертрофію нейронів PVHmp і підвищувала концентрацію РНК у цитоплазмі на 37 \%. Індикатором реакції нейронів PVHmp на гіпоксію було зростання в них концентрації білка HIF-1a у 2,5 раза. Гіпоксичні впливи підвищували концентрацію білка cFos y PVHmp на 37 \%, збільшували площу імунореактивності до AVP у 2,5 раза, до CRH і ß-ендоорфіну - втричі. Встановили посилення синтезу нейропептидів у відповідь на гіпоксію, що призводило до збільшення концентрації AVP у PVHmp у 6,6 раза, $\beta$-ендорфіну в 7 разів, $\mathrm{CRH}$ у 8,5 раза. У постгіпоксичний період зберігалися на високому рівні показники імунореактивності до білка HIF-1a 
і його концентрація в PVHmp. Встановили високі показники імунореактивності до CRH і $\beta$-ендорфріну в PVHmp, a також високу концентрацію цих нейропептидів у нейронах на тлі пригнічення синтезу AVP. Можливо, високі показники нейросекреторної активності PVHmp у постгіпоксичний період можуть свідчити про формування нейроендокринних механізмів адаптації гіпоталамо-гіпофізарно-адренокортикальної осі до тривалої дії гіпоксії.

Висновки. Переривчаста гіпобарична гіпоксія стимулює нейросекреторну активність нейронів PVHmp, збільшує синтез і секрецію гормонів CRH i AVP, що активують гіпоталамо-гіпофрізарно-адренокортикальну вісь. Синтез білків-індикаторів секреторної відповіді пептидергічних нейронів (білка cFos) і клітинної реакції на гіпоксію (білка HIF-1a) також наростає. Високі показники нейросекреторної активності PVHmp у постгіпоксичний період зберігаються і свідчать про формування нейроендокринних механізмів адаптації гіпоталамо-гіпофрізарно-адренокортикальної осі до тривалої дії гіпоксії.

\section{Нейроэндокринная реакция мелкоклеточных нейронов паравентрикулярного ядра гипоталамуса при прерывистом действии гипобарической гипоксии}

\section{В. А. Шаменко, Е. В. Каджарян, А. В. Абрамов}

Нейроэндокринная система занимает важное место в системных механизмах ответа организма на стресс. Паравентрикулярные ядра гипоталамуса (PVH) определяют реактивность гипоталамо-гипофизарно-адренокортикальной оси в ответ на действие стрессора любой природы и обеспечивают тем самым развитие адаптационных реакций и формирование резистентности организма к стрессу.

Цель работы - изучить особенности функционального состояния пептидергических нейронов медиального мелкоклеточного субъядра паравентрикулярного ядра гипоталамуса (PVHmp) при многодневном действии прерывистой гипобарической гипоксии и в постгипоксический период.

Материалы и методы. Исследование проведено на 24 самцах крыс линии Wistar. Прерывистую гипоксию моделировали ежедневным 6-часовым пребыванием крыс на высоте 6000 м ( $\left.\mathrm{pO}_{2}=9,8 \%\right)$ в течение 15 дней, постгипоксический период длился 10 дней. Распределение кортикотропин-рилизинг гормона (CRH), [Arg $\left.{ }^{8}\right]$-вазопрессина (AVP), $\beta$-эндорфина, белков cFos и HIF-1 $\alpha$ исследовали методами количественной иммунофлуоресценции в серийных фронтальных срезах гипоталамуса.

Результаты. Прерывистая гипобарическая гипоксия стимулировала умеренную гипертрофию нейронов PVHтр и повышала концентрацию РНК в цитоплазме на 37 \%. Индикатором реакции нейронов PVHmp на гипоксию было нарастание в них концентрации белка HIF-1a в 2,5 раза. Прерывистая гипоксия повышала концентрацию белка cFos в PVHmp на 37 \%, увеличивала площадь иммунореактивности к AVP в 2,5 раза, а к CRH и $\beta$-endorphin - в 3 раза. Отмечено усиление синтеза нейропептидов в ответ на гипоксию, что приводило к нарастанию концентрации AVP в PVHmp в 6,6 раза, $\beta$-эндорфина в 7 раз, CRH в 8,5 раза. В постгипоксический период на высоком уровне сохранялись показатели иммунореактивности к белку HIF-1 $а$ и его концентрация в PVHmp. Отмечены высокие показатели иммунореактивности к CRH и ß-эндорфину в PVHmp, а также высокая концентрация этих нейропептидов в нейронах на фоне угнетения синтеза AVP. Возможно, высокие показатели нейросекреторной активности PVHmp в постгипоксический период могут свидетельствовать о формировании нейроэндокринных механизмов адаптации гипоталамо-гипофизарно-адренокортикальной оси к длительному действию гипоксии.

Выводы. Прерывистая гипобарическая гипоксия стимулирует нейросекреторную активность нейронов PVHmp, увеличивает синтез и секрецию гормонов CRH и AVP, активирующих гипоталамо-гипофризарно-адренокортикальную ocь. Синтез белков-индикаторов секреторного ответа пептидергических нейронов (белка cFos) и клеточной реакции на гипоксию (белка HIF-1a) также нарастает. Высокие показатели нейросекреторной активности PVHmp в постгипоксический период сохраняются и свидетельствуют о формировании нейроэндокринных механизмов адаптации гипоталамо-гипофизарно-адренокортикальной оси к длительному действию гипоксии.

The brain is the central organ of the body adaptation to various social and physical stressors, because it determines the strategy of neurophysiological, neuroendocrine and behavioral reactions, which can be either destructive or protective for the organism in conditions of acute or chronic stress. Brain reactions are associated not only with the stimulation of the hypothalamic-pituitary-adrenal axis (HPA) and the autonomic nervous system, but also with the regulatory effects of these systems on the metabolism and the activity of pro- and anti-inflammatory components of the immune system [1,2]. The paraventricular nuclei of the hypothalamus $(\mathrm{PVH})$ are one of the most important links of the brain neuroendocrine system they determine the reactivity of the HPA axis in response to the various stressors and thereby ensure the development of adaptive reactions by the formation of body resistance to the stress $[3,4]$. The key mechanism of the HPA axis activation is formed due to the secretion of corticotropin-releasing hormone $(\mathrm{CRH})$ in the neurons of the medial parvocellular nuclei of the PVH (PVHmp) [5,6]. The concentration of ACTH and glucocorticoids in the blood increases because $\mathrm{CRH}$ triggers the cascade of the integrated neuroendocrine response of the adenohypophysis and adrenal cortex to stress [5,7]. A degree of glucocorticoid secretion elevation significantly defines the strength and specificity of stress action and the consequences of its influence on the organism $[7,8]$. The neurosecretory cells of PVHmp in addition to $\mathrm{CRH}$ synthesize [Arg8]-vasopressin (AVP), which has a stimulating and, together with $\mathrm{CRH}$, permissive effects on the ACTH and corticosteroids synthesis $[4,9,10]$. Also these structures produce $\beta$-endorphin, which regulates the intensity of the neuroendocrine stress response [11].

The hypoxic hypoxia due to the nature of its action on the organism is considered to be a universal stressor. The
Киючевые слова: гипоталамус, нейрогормоны, прерывистая гипобарическая гипоксия, аАаптация.

Патология. - 2019. T. 16, № 3(47). C. 334-338 
long-term dosed hypoxic effects cause a stable increase in the body overall resistance to many pathogens such as acute hypoxia, hypercapnia, hyperoxia, hypokinesia, ionizing radiation, physical activity $[4,12,13]$. The most effective way to increase the body resistance is to use the intermittent breathing regime with gas mixtures containing $14-16 \% \mathrm{O}_{2}$ for humans and $8-11 \%$ for laboratory rats $[12,14]$. Single studies carried out on rats showed that a single 2-hour $\left(\mathrm{pO}_{2}=10 \%\right)$ [15], as well as a 3-week (6 hours, $\mathrm{pO}_{2}=9.8 \%$ ) $[16,17]$ hypoxic hypoxia action led to the hypertrophy of peptidergic $\mathrm{PVH}$ neurons and to an increase in immunoreactivity to $\mathrm{CRH}$, AVP and $\beta$-endorphin in the hypothalamus.

\section{The aim}

The aim of the work was to study the functional state of the peptidergic neurons of the medial parvocellular nuclei of the paraventricular hypothalamic nucleus (PVHmp) during the multi-day action of intermittent hypobaric hypoxia and in the posthypoxic period.

\section{Materials and methods}

Experimental animals. The study was carried out on adult male Wistar rats 220-250 g weight, which were divided into 3 groups of 8 animals in each: 1 ) intact animals (control), 2 ) animals with 15-day hypoxic training, 3) animals with 10-day rest after hypoxic training (post-hypoxic period). The animals were kept in standard vivarium conditions under natural light without restriction of access to water and food. The studies were conducted in accordance with the requirements of international principles of the European Convention (Strasbourg, 1985).

Simulation of intermittent hypobaric hypoxia. Intermittent hypobaric hypoxia $(\mathrm{IHH})$ was modeled by daily 6-hour stay of rats in a ventilated pressure chamber (volume $1.0 \mathrm{~m}^{3}$ ): from the $1^{\text {st }}$ to the $5^{\text {th }}$ days the exposure's altitude was increased daily by $1000 \mathrm{~m}$, in the next 10 days the animals were at the altitude of $6000 \mathrm{~m}\left(\mathrm{pO}_{2}=75 \mathrm{~mm}\right.$ $\mathrm{Hg}$, that corresponds to the concentration of $9.8 \%$ oxygen in air at normal atmospheric pressure).

Preparation for histology. All intact rats, and $24 \mathrm{~h}$ after last $\mathrm{IHH}$ for animals from $2^{\text {nd }}$ experimental group, and $24 \mathrm{~h}$ after 10 days of post-hypoxic period for animals from $3^{\text {rd }}$ experimental group were deeply anesthetized with thiopental sodium (50 mg/kg ip). The brains were immediately removed and placed in Carnoy's solution ( 3 brains from each experimental group, for histochemistry) or Bouin's solution ( 5 brains from each experimental group, for immunofluorescence) for $20 \mathrm{~h}$ at room temperature. The brains were poured into paraplast (McCormick, USA) after standard histological processing. Coronal slices of the brain $7 \mu \mathrm{m}$ for Carnoy's fixation and $14 \mu \mathrm{m}$ for Bouin's fixation through the hypothalamic PVN were cut on a rotary microtome Microm-325 (Microm Corp., Germany).

Histochemistry and morphometry. Serial histological slices were dewaxed with xylene and rehydrated with descending concentrations of ethanol. Then, slices were stained with hallocyanin and chromium alum by the Einarson method during $48 \mathrm{~h}$. The stained sections were washed in water, dehydrogenated with ascending concentrations of ethanol, xylem, and polymer medium
EUKITT (O. Kindler GmbH, Germany) embedded. The digital images of the PVHmp were taking using a CCD microscope camera COHU-4922 (COHU Inc., USA) and an Axioskop microscope (Carl Zeiss, Germany), and were converted to a gray scale (0-255). All images were analyzed using application-oriented image analysis system software VIDAS-2.5 (Kontron Elektronik GmbH, Germany). More than 100 neurons were examined in each experimental group, and the following parameters were measured and calculated: the area of neurons $\left(\mathrm{mcm}^{2}\right)$, and the RNA concentration (relative units of optical density $-U_{O D}$ ).

Immunofluorescence technique and quantitative analysis. Serial histological slices were dewaxed and unmasked in a citrate buffer solution ( $\mathrm{pH}=9.0)$ in the PT-module (Thermo Scientific, USA). CRH, AVP, $\beta$-endorphin, cFos, and HIF-1a proteins in the PVHmp were detected by immunofluorescence method using antibodies produced by Santa Cruz Biotechnology (USA). Primary antibodies were incubated in dilution 1:100 (wet chamber, $\mathrm{T}=+4^{\circ} \mathrm{C}$, 24 hours), secondary antibodies conjugated with FITC were incubated in dilution 1:64 (wet chamber, $\mathrm{T}=+37^{\circ} \mathrm{C}$, $45 \mathrm{~min}$ ). The slices were washed in phosphate buffer and then enclosed in a mixture of glycerin/phosphate buffer (9:1). Specificity of antibody binding was controlled in a similar way, except for incubation with primary antibodies. Immunofluorescence reaction was studied using the AxioImager-M2 fluorescence microscope (Carl Zeiss, Germany) with the 12-bit digital camera AxioCam-HRm (Carl Zeiss, Germany) and with the use of the high-emission 38HE filter $\left(\lambda_{\mathrm{ex}}=470 / 40 \mathrm{~nm}, \lambda_{\mathrm{em}}=525 / 50 \mathrm{~nm}\right)$ (Carl Zeiss, Germany). Quantitative analysis of the immunofluorescence reaction was carried out using digital image analysis system software AxioVision-4.8.2 (Carl Zeiss, Germany). At least 4 hypothalamic regions with $\mathrm{PVHmp}$ were examined in each brain, and the following parameters were measured and calculated: the relative area of the immunopositive material (the percentage of the immunopositive material in the area of the PVHmp), and the concentration of proteins in endocrinocytes (the module of the logarithm of the background fluorescence to the fluorescence of immunopositive material ratio, expressed in relative units of fluorescence $-U_{\mathrm{IF}}$ ).

Statistics. The results are reported as mean \pm S.E.M. Experimental data were processed with the EXCEL 2003 (Microsoft Corp.) statistical analysis software package. The significance of the differences between the experimental groups was assessed using the Student's criterion $t$, considering the differences to be reliable at $P<0.05$.

\section{Results}

The intermittent hypobaric hypoxia $(\mathrm{HH})$ stimulated the developing of mild hypertrophy of PVHmp neurons. These changes manifested by an increase in the neurons body area by $10 \%$ as well as the concentration of RNA in the cytoplasm by $37 \%$ (Table 1). It is known that normal parvocellular PVHmp neurons in rats have poor cytoplasm, less neurosecretory granules and low quantity of neuropeptides in the cytoplasm which can be seen during immunohistochemical reactions. Nevertheless, an increase in the area of the neuronal cytoplasm after $\mathrm{IHH}$ and the elevation in the RNA level may be the evidence of the enhanced functional and secretory activity of PVHmp. An indicator of the neurosecretory activity 
Table 1. Indicators of the functional activity of the PVHmp neurons $(\mathrm{M} \pm \mathrm{m})$

\begin{tabular}{|c|c|c|c|c|}
\hline \multirow[t]{2}{*}{ Indicators (Markers) } & & \multicolumn{3}{|c|}{ Experimental groups of animals } \\
\hline & & Control & Intermittent hypobaric hypoxia & Post-hypoxic period \\
\hline Area of neurons, $\mathrm{mcm}^{2}$ & & $88.71 \pm 1.76$ & $98.08 \pm 1.97^{*}$ & $123.21 \pm 2.45^{\star \#}$ \\
\hline RNA & concentration, $U_{O D}$ & $4.50 \pm 0.16$ & $6.16 \pm 0.33^{*}$ & $5.87 \pm 0.28^{*}$ \\
\hline \multirow[t]{2}{*}{$\mathrm{CRH}$} & area of IRM, \% & $1.19 \pm 0.21$ & $3.56 \pm 0.29^{*}$ & $1.88 \pm 0.15^{\star \#}$ \\
\hline & concentration, $U_{\mathrm{IF}}$ & $0.46 \pm 0.08$ & $3.92 \pm 0.33^{*}$ & $1.46 \pm 0.15^{*}$ \\
\hline \multirow[t]{2}{*}{ AVP } & area of IRM, \% & $22.71 \pm 2.43$ & $55.72 \pm 1.58^{*}$ & $5.23 \pm 0.19^{\star \#}$ \\
\hline & concentration, $\mathrm{U}_{\mathrm{IF}}$ & $0.77 \pm 0.07$ & $5.13 \pm 0.32^{*}$ & $0.47 \pm 0.03^{* \#}$ \\
\hline \multirow[t]{2}{*}{$\beta$-endorphin } & area of IRM, \% & $0.81 \pm 0.12$ & $2.51 \pm 0.25^{\star}$ & $1.74 \pm 0.19^{* \#}$ \\
\hline & concentration, $\mathrm{U}_{\mathrm{IF}}$ & $0.35 \pm 0.05$ & $2.49 \pm 0.26^{*}$ & $2.03 \pm 0.16^{*}$ \\
\hline \multirow[t]{2}{*}{ cFos } & area of IRM, \% & $4.14 \pm 0.32$ & $4.63 \pm 0.25$ & $3.92 \pm 0.26$ \\
\hline & concentration, $\mathrm{U}_{\mathrm{IF}}$ & $1.83 \pm 0.19$ & $2.51 \pm 0.11^{*}$ & $1.88 \pm 0.21^{\#}$ \\
\hline \multirow[t]{2}{*}{$\mathrm{HIF}-1 \alpha$} & area of IRM, \% & $2.67 \pm 0.10$ & $4.24 \pm 0.37^{*}$ & $4.55 \pm 0.31^{*}$ \\
\hline & concentration, $\mathrm{U}_{\mathrm{IF}}$ & $0.20 \pm 0.01$ & $0.49 \pm 0.03^{*}$ & $0.40 \pm 0.03^{\text {*\# }}$ \\
\hline
\end{tabular}

IRM: immunoreactive material, $U_{0 D}$ : units of optical density, $U_{I F}$ : units of immunofluorescence, significance $P<0.05$ of differences in comparison with control $(*)$ and with rats after the finish of $\mathrm{IHH}\left({ }^{*}\right)$.

of hypothalamic neurons is the cFos protein. Indeed, the $\mathrm{HHH}$ elevated the cFos protein concentration in PVHmp by $37 \%$, increased the area of immunoreactivity to AVP by 2.5 times as well as to $\mathrm{CRH}$ and $\beta$-endorphin by 3 times. The icreasing of immunoreactivity indicated the neuropeptides synthesis enhancement and the elevation of the concentration of AVP in PVHmp by 6.6 times, $\beta$-endorphin by 7 times and $\mathrm{CRH}$ by 8.5 times in response to $\mathrm{IH}$.

We believe that the increasing of the neuroendocrine reaction of PVHmp neurons is directly caused by hypoxia and can be mediated by the hif-1 $\alpha$ gene activation. Really, under the influence of $\mathrm{IHH}$ the area of immunoreactivity to HIF-1a in PVHmp was $60 \%$ increased, as well as the concentration of HIF-1a protein was 2.5 times elevated. The data obtained indicate that $\mathrm{IHH}$ stimulates the neurosecretory activity of PVHmp neurons and leads to an increase in the synthesis and secretion of hormones that activate HPA.

It's an interesting fact that after a 10-day posthypoxic period, signs of mild hypertrophy of PVHmp neurons persisted. Moreover, the area of neurons increased by $25 \%(P<0.05)$ in comparison with the $\mathrm{IHH}$ end date. The immunoreactivity indices for the HIF-1a protein and its concentration in PVHmp remained at a high level against the background of the restoration of the concentration of the marker of the cFos protein neurosecretory activity (Table 1). Despite this, high immunoreactivity to $\mathrm{CRH}$ and $\beta$-endorphin remained in PVHmp, as well as a high concentration of these neuropeptides in neurons. At the same time, during the posthypoxic period, the area of AVP immunoreactivity was 4 times reduced, and the concentration of this neurohormone in PVHmp neurons was decreased by $40 \%$ as compared with the control. It is possible that high rates of neurosecretory activity of PVHmp in the posthypoxic period may indicate the formation of neuroendocrine mechanisms of adaptation of the HPA axis to the long-term effect of hypoxia.

\section{Discussion}

Considering the mechanisms of the body adaptation to social and physical stressors, it should be understood that the brain is a key link in adaptation since it determines the specificity of the stressor, its intensity and potential threat to the organism. The brain stores in memory not only the fact of the stressor action, but also the sequence of physiological and beha- vioral responses to the stress as well as the effectiveness of the chosen response strategy, which can be either protective or destructive for the body. One of the common stressors the organism can be faced by is hypoxia. Even during embryogenesis hypoxia stimulates neurogenesis and is necessary for normal brain development, although intense hypoxia can lead to brain damage. [18]. In adults, periodic hypoxia is a concomitant pathogenic factor that accompanies many clinical diseases, such as sleep apnea, chronic obstructive pulmonary disease, pulmonary fibrosis and nocturnal asthma [19]. At the same time, preconditioning and adaptation to hypoxia protects the brain from acute hypoxic damage [18] and also causes a persistent increase in the body overall resistance to many pathogens $[4,12,13]$.

Among the varied brain structures involved in response strategy choice to the stress of diverse etiology, PVH seems to be the most important structure that regulates HPA activity through $\mathrm{CRH}$ secretion $[1,2]$. It has also been proven with respect to the role of $\mathrm{PVH}$ and HPA in adapting to long term hypoxia [20]. The physiological significance of HPA in adaptation mechanisms is determined by the key role of glucocorticoids, which can influence on neuronal plasticity using genomic and non-genomic effects [2,21]. Glucocorticoids can directly stimulate release of excitatory amino acids via membrane-associated receptors, and they can indirectly regulate both glutamate and GABA release through induction of local synthesis of endocannabinoids [22]. In addition, glucocorticoids can also regulate mitochondrial oxidation and free radical formation and membrane potential, and affect apoptosis via $\mathrm{Bcl}-2 / \mathrm{Bax}$ proteins [23]. Furthermore, $\mathrm{CRH}$, which is synthesized in PVHmp, plays a key role in stress-induced hippocampal dendritic remodeling in the CA1 region [24].

Our studies convincingly demonstrate that $\mathrm{IHH}$ considerably elevates the neuroendocrine potential of PVH not only at the end of hypoxic trainings, but also retains it in the remote posthypoxic period. This preserves the increased functional level of HPA activity for a long time and reflects the formation of a stable systemic structural trace of adaptation to hypoxia.

\section{Conclusions}

1. Intermittent hypobaric hypoxia stimulates the neurosecretory activity of the PVHmp neurons, increases 
the synthesis and secretion of $\mathrm{CRH}$ and AVP hormones that activate the HPA axis. Synthesis of the secretory response indicator $\mathrm{CFos}$ protein and a central regulator of hypoxic responses HIF-1 a protein is also increasing in the peptidergic neurons of the PVHmp.

2. High levels of the PVHmp neurosecretory activity at the posthypoxic period are preserved and indicate the formation of neuroendocrine mechanisms of the HPA axis adaptation to the long term intermittent hypoxia exposures.

Prospects for further research. Future studies will focus on the response of the neuroendocrine hypothalamus to hypoxia by such factors as hypoxia-induced factors 1 and 3, vascular endothelial growth factor, both pro- and anti-apoptotic stimulators of cell death.

Conflicts of interest: authors have no conflict of interest to declare. Конфмікт інтересів: віАсутній.

Надійшла Ао реАакції / Received: 01.10.2019

Після Аоопрацювання / Revised: 22.10.2019

Прийнято Ао Аруку / Accepted: 04.11.2019

\section{Information about authors:}

Shamenko V. O., MD, Assistant Professor of the Department of Children Diseases, Zaporizhzhia State Medical University, Ukraine. Kadzharian Ye. V., MD, PhD, Associate Professor of the Department of Pathological Physiology of Zaporizhzhia State Medical University, Ukraine.

Abramov A. V., MD, PhD, DSc, Professor of the Department of Pathological Physiology of Zaporizhzhia State Medical University, Head of Scientific Medical-Laboratory Center of ZSMU, Ukraine.

\section{Відомості про авторів:}

Шаменко В. О., лікар вищої категорії, асистент каф. Аитячих хвороб, Запорізький державний медичний університет, Україна. Каджарян Є. В., канА. меА. наук, Аоцент каф. патологічної фізіології, Запорізький державний медичний університет, Україна.

Абрамов А. В., А-р меА. наук, професор каф. патологічної фізіології, керівник Навчального меАико-лабораторного центру, Запорізький Аержавний медичний університет, Україна.

\section{Сведения об авторах:}

Шаменко В. А., врач высшей категории, ассистент каф. Аетских болезней, Запорожский государственный меАицинский университет, Украина.

КаАжарян Е. В., канА. меА. наук, Аоцент каф. патологической физиологии, Запорожский государственный меАицинский университет, Украина.

Абрамов А. В., А-р меА. наук, профессор каф. патологической физиологии, руководитель Учебного медико-лабораторного центра, Запорожский государственный меАицинский университет, Украина.

\section{References}

[1] McEwen, B. S. (2009). The brain is the central organ of stress and adaptation. Neuroimage, 47(3), 911-913. https://doi.org/10.1016/j. neuroimage.2009.05.071

[2] McEwen, B. S., Bowles, N. P., Gray, J. D., Hill, M. N., Hunter, R. G., Karatsoreos, I. N., \& Nasca, C. (2015). Mechanisms of stress in the brain. Nature Neuroscience, 18(10), 1353-1363. https://doi.org/10.1038/ nn. 4086

[3] Meerson, F. Z. (1981). Adaptatsiya, stress i profilaktika [Adaptation, stress and prevention]. Moscow: Nauka. [in Russian].

[4] McEwen, B. S. (2007). Physiology and neurobiology of stress and adaptation: Central role of the brain. Physiological Reviews, 87(3), 873-904. https://doi.org/10.1152/physrev.00041.2006

[5] Bonfiglio, J. J., Inda, C., Refojo, D., Holsboer, F., Arzt, E., \& Silberstein, S. (2011). The Corticotropin-Releasing Hormone Network and the Hypothalamic-Pituitary-Adrenal Axis: Molecular and Cellular
Mechanisms Involved. Neuroendocrinology, 94(1), 12-20. https://doi. org/10.1159/000328226

[6] Swanson, L. W., \& Sawchenko, P. E. (1983). Hypothalamic integration - organization of the paraventricular and supraoptic nuclei. Annual Review of Neuroscience, 6, 269-324. https://doi.org/10.1146/annurev. ne. 06.030183 .001413

[7] Reznikov, A. G. (2007). Endokrinologicheskie aspekty stressa [Endocrinological Aspects of Stress]. Mezhdunarodnyi endokrinologicheskil zhurnal, (4), 20-24. [in Russian].

[8] Busnardo, C., Tavares, R. F., Resstel, L. B. M., Elias, L. L. K., \& Correa, F. M. A. (2010). Paraventricular nucleus modulates autonomic and neuroendocrine responses to acute restraint stress in rats. $\mathrm{Au}$ tonomic Neuroscience-Basic \& Clinical, 158(1-2), 51-57. https://doi. org/10.1016/.autneu.2010.06.003

[9] Volpi, S., Rabadan-Diehl, C., \& Aguilera, G. (2004). Vasopressinergic regulation of the hypothalamic pituitary adrenal axis and stress adaptation. Stress-the International Journal on the Biology of Stress, 7(2), 75-83. https://doi.org/10.1080/10253890410001733535

[10] Sivukhina, E. V., \& Jirikowski, G. F. (2016). Magnocellular hypothalamic system and its interaction with the hypothalamo-pituitary-adrenal axis. Steroids, 111, 21-28. https://doi.org/10.1016/j.steroids.2016.01.008

[11] Kovalitskaya, Y. A., \& Navolotskaya, E. V. (2011). Nonopioid effect of beta-endorphin. Biochemistry-Moscow, 76(4), 379-393. https://doi. org/10.1134/s0006297911040018

[12] Berezovskiy, V. A. (2012). Tsvetok Gil'gamesha. Prirodnaya i instrumental'naya oroterapiya : (ocherki o gorakh i ikh vliyanii na organizm cheloveka) [Flower of Gilgamesh. Natural and instrumental orotherapy (essays of the mountains and their effects on the human body)]. Donetsk: Publisher Zaslavsky A.Yu. [in Russian].

[13] Karash, Yu. M., Strelkov, R. B., \& Chizhov F. Ya. (1988). Normobaricheskaya gipoksiya v lechenii, profilaktike i reabilitatsii [Intermittent Normobaric Hypoxia for Treatment, Prevention, and Rehabilitation Purposes]. Moscow: Izdatelstvo Meditsina. [in Russian].

[14] Xi, L, \& Serebrovskaya, T. V. (2009). Intermittent hypoxia: from molecular mechanisms to clinical applications, 1st ed. New York: Nova Science Publishers, Inc.

[15] Coldren, K. M., Li, D. P., Kline, D. D., Hasser, E. M., \& Heesch, C. M. (2017). Acute hypoxia activates neuroendocrine, but not presympathetic, neurons in the paraventricular nucleus of the hypothalamus: differential role of nitric oxide. American Journal of Physiology-Regulatory Integrative and Comparative Physiology, 312(6), R982-R995. https:Il doi.org/10.1152/ajpregu.00543.2016

[16] Kolesnik, Yu. M., Orestenko, Yu. N., \& Abramov, A. V. (1993) Sostoyanie vazopressin-, oksitocin-i kortikoliberinsinteziruyushchikh struktur gipotalamusa u krys s sakharnym diabetom pri gipoksicheskikh vozdejstviyakh [The state of vasopressin-, oxytocin- and corticoliberin-synthesizing structures of the hypothalamus in diabetic rats with hypoxic effects]. Fiziologicheskii zhurnal im. I. M. Sechenova, 79(9), 34-42. [in Russian].

[17] Abramov, A. V. (1998) Vliyanie interval'nykh gipoksicheskikh trenirovok na funktsional'noe sostoyanie peptidergicheskikh neironov paraventrikulyarnogo yadra gipotalamusa i neironov stvola mozga krys [The effect of interval hypoxic training on the functional state of the peptidergic neurons of the paraventricular nucleus of the hypothalamus and rat brainstem neurons]. Rossiiskii fiziologicheskii zhurnal im. I.M. Sechenova, 84(3), 173-181. [in Russian].

[18] Basovich, S. N. (2013). Trends in the use of preconditioning to hypoxia for early prevention of future life diseases. Bioscience Trends, 7(1) 23-32. https://doi.org/10.5582/bst.2013.v7.1.23

[19] Zhang, S. X. L., Wang, Y., \& Gozal, D. (2012). Pathological Consequences of Intermittent Hypoxia in the Central Nervous System. Comprehensive Physiology, 2(3), 1767-1777. https://doi.org/10.1002/ cphy.c100060

[20] Myers, D. A., \& Ducsay, C. A. (2014). Altitude, Attitude and Adaptation. Advances in Fetal and Neonatal Physiology, 814, 147-157. https://doi. org/10.1007/978-1-4939-1031-1_13

[21] Peters, A., McEwen, B. S., \& Friston, K. (2017). Uncertainty and stress: Why it causes diseases and how it is mastered by the brain. Progress in Neurobiology, 156, 164-188. https://doi.org/10.1016/j. pneurobio.2017.05.004

[22] Gray, J. M., Wilson, C. D., Lee, T. T. Y., Pittman, Q. J., Deussingh, J. M., Hillard, C. J., ... Hill, M. N. (2016). Sustained glucocorticoid exposure recruits cortico-limbic $\mathrm{CRH}$ signaling to modulate endocannabinoid function. Psychoneuroendocrinology, 66, 151-158. https://doi. org/10.1016/j.psyneuen.2016.01.004

[23] Du, J., Wang, Y., Hunter, R., Wei, Y. L., Blumenthal, R., Falke, C., ... Manji, H. K. (2009). Dynamic regulation of mitochondrial function by glucocorticoids. Proceedings of the National Academy of Sciences of the United States of America, 106(9), 3543-3548. https://doi. org/10.1073/pnas.0812671106

[24] Chen, Y., Fenoglio, K. A., Dube, C. M., Grigoriadis, D. E., \& Baram, T. Z. (2006). Cellular and molecular mechanisms of hippocampal activation by acute stress are age-dependent. Molecular Psychiatry, 11(11), 992 1002. https://doi.org/10.1038/sj.mp.4001863 